\title{
Wheat flour as dietary fiber on fresh and preserved beef meatballs
}

\author{
Jamaly ${ }^{1}$ S I, MA Hashem ${ }^{*}$, S Akhter ${ }^{1}$ and MA Hossain ${ }^{1}$
}

${ }^{1}$ Department of Animal Science, Faculty of Animal Husbandry, Bangladesh Agricultural University, Mymensingh2202, Bangladesh

\begin{abstract}
Effects of different levels of wheat flour as dietary fiber on the quality of fresh and preserved beef meatballs during storage were explored in this study. Ground beef (Batter) samples were divided into four treatment groups and treated with different level of wheat flour as $T_{1}$ (control, $\left.0 \%\right), T_{2}(5 \%), T_{3}$ $(10 \%)$ and $\mathrm{T}_{4}(15 \%)$. Proximate analysis (dry matter, ash, ether extract and crude fat), sensory tests (color, flavor, tenderness, juiciness, overall acceptability), biochemical analysis (free fatty acids, Thiobarbutiric acid values and peroxide value) and microbiological examination were carried out as responses at the interval of 0,30 and 60 days during storage at $-20^{\circ} \mathrm{C}$. The experimental design was a 4 $\times 3$ factorial in Completely Randomized Design replicated three times per cell. DM content was increased significantly $(p<0.05)$ with the advancement of storage intervals. CP and EE content of all the treatments were decreased significantly $(p<0.05)$ among the different treatment groups. FFA and TBARs values were differed significantly $(p<0.05)$ at different treatment levels. PVs were decreased significantly $(p<0.05)$ at different treatment levels. Color, cooking loss and overall acceptability were differed significantly $(p<0.05)$ at different treatment levels. Raw and cooked $p^{H}$ were increased significantly $(p<0.05)$ at different treatment levels. The juiciness at different treatment levels were decreased significantly $(\mathrm{p}<0.05)$.TVC $(\log \mathrm{CFU} / \mathrm{g})$, TCC $(\log \mathrm{CFU} / \mathrm{g})$ and TYMC $(\log \mathrm{CFU} / \mathrm{g})$ were differed significantly $(p<0.05)$ at different treatment levels. In conclusions, meatballs having $5 \%$ wheat flour was better in terms of color, odor, tenderness, juiciness and overall acceptability, cooking loss and microbial qualities.
\end{abstract}

Key words: wheat flour, sensory, PV, FFA, TBARS, microbiological values

Bangladesh Animal Husbandry Association. All rights reserved.

Bang. J. Anim. Sci. 2017. 46 (1): 35-43

\section{Introduction}

Various types of meat products are prepared from meat. Among the different meat products, meatball is one of the tasty and popular foods. Meatball can be made with beef, lamb, veal pork, turkey, chicken and even offal. Meatball is one kind of ready-to-eat food product which is gaining popularity day by day. Yet, fat is an important constituent of human nutrition and contribute to the flavor, tenderness, juiciness, appearance, texture and shelf life of meat products. Thus, the challenge for meat industry is to develop low-fat meat products without compromising sensory and texture characteristics (Zhang et al., 2011). In addition, the nutritional profile of meat products could be further improved by addition of potentially health promoting ingredients. If dietary fiber used as an ingredients in meat products fat content will be reduced.
Dietary fiber is one of the essential vital food ingredients for human health in various aspects. Dietary fiber is the non-digestible form of carbohydrates and lignin. There is an increased demand for foods with more fiber and less fat as they are very effective in prevention of fat absorption by the product, particularly fatty acids and cholesterol by Borderias et al., (2005) that could be useful in reducing obesity. Various types of fiber have been studied alone or combined with other ingredients for formulations of reduced fat meat products. Specially, increased consumption of dietary fiber lowers serum lipid concentrations and blood pressure, improves blood glucose control in diabetes, and aids in weight loss by increasing satiety. Current recommendations for dietary fiber intake are 25 $\mathrm{g} / \mathrm{d}$ for women and $38 \mathrm{~g} / \mathrm{d}$ for men in the United States (USDA, 2010) and $20 \mathrm{~g} / \mathrm{d}$ for women and $25 \mathrm{~g} / \mathrm{d}$ for men in Korea (KNS, 2010).

*Corresponding author: hashem_mdabul@bau.edu.bd 


\section{Wheat flour on beef meatballs}

Along with health and nutritional benefits, dietary fiber has various suitable functional properties which affect the quality and characteristics of food products. The major functional properties of dietary fiber are water holding capacity, viscosity, gel-forming ability, and fat binding capacity. Dietary fiber as a functional ingredient can be incorporated with meat products to improve health view of meat products. Potential dietary fiber sources from various cereals, legumes, fruits and vegetables could be used as functional ingredients in meat products by judicious processing methods.

The use of wheat flour, known as the best source of insoluble dietary fiber, was used as a fat substitute in the production of beef patties (Saricoban et al., 2009). The use of wheat flour has gained a very positive attention to consumers because of health benefits associated with its consumption. Health benefits of wheat-based food products are attributed to the soluble dietary fiber in oats, (1-3), (1-4)- $\beta$-D- glucan, referred to as $\beta$ - glucan. Chicken meat patties prepare with wheat bran at 5,10 and $15 \%$ levels increased cooking yield and firmness as well as insoluble fiber content (Talukder and Sharma, 2010). According to "Regulations on Nutrition Claims for conventional Foods", food products marked as "high fiber" must contain at least $6 \mathrm{~g}$ of dietary fiber for every $100 \mathrm{~g}$ of solid food and food products marked as "containing dietary fiber" must contain at least $3 \mathrm{~g}$ of dietary fiber for every $100 \mathrm{~g}$ of solid food (Chau et al., 1999). Considering the above discussion the present study was undertaken on proximate, physiochemical, sensory, biochemical and microbial quality of the beef meatballs and development of dietary fiber enriched value added functional meat products of commercial interest.

\section{Materials and methods}

\section{Materials collection}

Boneless beefof $2.5 \mathrm{~kg}$ from freshly slaughtered cattle was collected from "Sheep \& Goat \& Horse Farm" Bangladesh Agricultural University, Mymensingh. The meat sample was immediately transferred to the "Animal Science Laboratory".

\section{Preparation of jar and other instruments}

All necessary instruments and jars or containers were cleaned with hot water and detergent powder, and then dried properly before starting the experimental activities.

\section{Sample preparation}

About $2.5 \mathrm{~kg}$ of fresh beef sample was taken for the preparation of beef meatball. First the beef was properly cleaned with fresh water and the fat was trimmed of with sharp knife. Then the beef was grinded properly and the spices, garam masala, salt, Ice flakes, refined wheat flower, sauce were mixed with the grinded beef properly as per experimental design. There were four treatment groups. These were treated as $\mathrm{T}_{1}$ (control no wheat flour), T2 (5\%wheat flour), T3 (10\% wheat flour) and $\mathrm{T}_{4}(15 \%$ wheat flour). Then beef meatball of proper shape was prepared separately. It was then boiled in hot water for 2-3 minutes. Then the water was removed from the meatball properly and was fried in hot oil until reddish brown color was obtained.

\section{Sensory evaluation}

Different sensory attributes were examined. Each meatball sample was evaluated by a trained 8member panel. The sensory questionnaires measured intensity on a 5-point balanced semantic scale (weak to strong) for the attributes of color, smell, tenderness, juiciness, and overall acceptability. Eight training sessions were held to familiarize the judges with the attributes to be evaluated and the scale to be used (Rubio et al., 2007). Prior to sample evaluation, all panelists participated in orientation sessions to familiarize with the scale attributes (color, odor, juiciness, tenderness, overall acceptability) of beef meatball using intensity scale. All samples were served in the Petri dishes. Sensory evaluation was accomplished at 0 day and repeated at 30 day and 60 day.

\section{Proximate composition}

Proximate composition such as Dry Matter (DM), Ether Extract (EE), Crude Protein (CP) and Ash were carried out according to the methods (AOAC, 2016). All determination was done in triplicate and the mean value was reported. 
Jamaly et al. (2017) Bang. J. Anim. Sci. 46 (1):35-43

\section{Biochemical analysis}

There were three types of biochemical analysis. These are Free Fatty Acid(FFA), Peroxide Value(POV), Thiobarbituric Acid value (TBARS). Free fatty acid value was determined according to Rukunudin et al. (1998). Peroxide value (POV) was determined according to Sallamet al. (2004). Lipid oxidation was assessed in triplicate using the2-thiobarbituric acid (TBA) method described by Schmedes and Holmer (1989). $\mathrm{p}^{\mathrm{H}}$ value of raw and cooked meatball was measured using $\mathrm{pH}$ meter from raw meatball homogenate. The homogenate was prepared by blending $5 \mathrm{~g}$ of meat with $10 \mathrm{ml}$ distilled water.

\section{Cooking loss}

The fresh meatball samples were weighted (initial weight). Firstly weighted meatballs boiled at water bath to $100^{\circ} \mathrm{C}$. After completed boiling samples were removed from the water bath and egg albumin, biscuit crumbs were mixed with all types of beef meatballs. Again all samples were cooked with refined soybean oil to $100^{\circ} \mathrm{C}$. After completed the frying of meatballs these were properly removed and kept at room temperature. Then they were covered with the thin walled plastic bags. After removing the surface oil of beef meatballs these fully prepared for measuring cooking loss. Cooking loss was practiced at 0 day, $30^{\text {th }}$ day and $60^{\text {th }}$ day.

Table 1. Effect of different levels of wheat flour on sensory parameters in beef meatball

\begin{tabular}{|c|c|c|c|c|c|c|c|c|c|}
\hline \multirow[t]{2}{*}{ Parameters } & \multirow[t]{2}{*}{ DI } & \multicolumn{4}{|c|}{ Treatments } & \multirow[t]{2}{*}{ Mean } & \multicolumn{3}{|c|}{ Level of significance } \\
\hline & & $\mathrm{T}_{1}$ & $\mathrm{~T}_{2}$ & $T_{3}$ & $\mathrm{~T}_{4}$ & & Treat & DI & $T * D I$ \\
\hline \multirow[t]{4}{*}{ Color } & 0 & $4.41 \pm 0.02$ & $4.75 \pm 0.02$ & $4.32 \pm 0.89$ & $4.07 \pm 0.02$ & $4.39 \pm 0.24^{a}$ & \multirow[t]{4}{*}{$<.0001$} & \multirow[t]{4}{*}{$<.0001$} & \multirow[t]{4}{*}{0.1449} \\
\hline & 30 & $4.25 \pm 0.04$ & $4.62 \pm 0.01$ & $4.33 \pm 0.02$ & $3.92 \pm 0.02$ & $4.28 \pm 0.02^{b}$ & & & \\
\hline & 60 & $4.05 \pm 0.02$ & $4.34 \pm 0.11$ & $3.87 \pm 0.01$ & $3.71 \pm 0.02$ & $3.99 \pm 0.04^{c}$ & & & \\
\hline & Mean & $4.24 \pm 0.03^{b b}$ & $4.57 \pm 0.05^{a}$ & $4.18 \pm 0.31^{b}$ & $3.90 \pm 0.02^{c}$ & & & & \\
\hline \multirow[t]{4}{*}{ Odor } & 0 & $4.33 \pm 0.33$ & $4.33 \pm 0.33$ & $4.00 \pm 0.00$ & $4.00 \pm 0.00$ & $4.17 \pm 0.17^{\mathrm{AA}}$ & \multirow{4}{*}{0.2869} & \multirow[t]{4}{*}{0.2178} & \multirow[t]{4}{*}{0.8319} \\
\hline & 30 & $4.33 \pm 0.33$ & $4.33 \pm 0.33$ & $4.33 \pm 0.33$ & $4.00 \pm 0.00$ & $4.25 \pm 0.25^{\mathrm{AA}}$ & & & \\
\hline & 60 & $3.66 \pm 0.33$ & $4.33 \pm 0.33$ & $4.00 \pm 0.00$ & $3.66 \pm 0.33$ & $3.92 \pm 0.25^{A}$ & & & \\
\hline & Mean & $4.11 \pm 0.33^{\text {aa }}$ & $4.33 \pm 0.33^{\text {aa }}$ & $4.11 \pm 0.11^{\text {aa }}$ & $3.89 \pm 0.11^{\mathrm{a}}$ & & & & \\
\hline \multirow[t]{4}{*}{ Tenderness } & 0 & $4.33 \pm 0.33$ & $4.00 \pm 0.00$ & $4.33 \pm 0.33$ & $4.33 \pm 0.33$ & $4.25 \pm 0.25^{\mathrm{aa}}$ & \multirow[t]{4}{*}{0.4098} & \multirow[t]{4}{*}{0.0037} & \multirow[t]{4}{*}{0.7086} \\
\hline & 30 & $4.33 \pm 0.33$ & $4.00 \pm 0.00$ & $4.33 \pm 0.33$ & $4.00 \pm 0.00$ & $4.17 \pm 0.17^{\mathrm{a}}$ & & & \\
\hline & 60 & $3.33 \pm 0.33$ & $3.66 \pm 0.33$ & $4.00 \pm 0.00$ & $3.33 \pm 0.33$ & $3.58 \pm 0.25^{\mathrm{a}}$ & & & \\
\hline & Mean & $4.00 \pm 0.33^{\text {aa }}$ & $3.89 \pm 0.11^{\text {aa }}$ & $4.22 \pm 0.22^{a a}$ & $3.89 \pm 0.22^{a}$ & & & & \\
\hline \multirow[t]{4}{*}{ Juiciness } & 0 & $4.82 \pm 0.01$ & $4.72 \pm 0.01$ & $4.64 \pm 0.01$ & $4.56 \pm 0.01$ & $4.69 \pm 0.11^{\mathrm{a}}$ & \multirow[t]{4}{*}{$<.0001$} & \multirow[t]{4}{*}{$<.0001$} & \multirow[t]{4}{*}{$<.0001$} \\
\hline & 30 & $4.60 \pm 0.01$ & $4.71 \pm 0.02$ & $4.53 \pm 0.01$ & $4.40 \pm 0.02$ & $4.56 \pm 0.02^{b}$ & & & \\
\hline & 60 & $4.53 \pm 0.01$ & $4.34 \pm 0.02$ & $3.89 \pm 0.03$ & $3.71 \pm 0.02$ & $4.12 \pm 0.02^{c}$ & & & \\
\hline & Mean & $4.62 \pm 0.01^{a}$ & $4.63 \pm 0.02^{a a}$ & $4.36 \pm 0.02^{b}$ & $4.23 \pm 0.02^{c}$ & & & & \\
\hline \multirow{4}{*}{$\begin{array}{l}\text { Overall } \\
\text { acceptability }\end{array}$} & 0 & $4.64 \pm 0.01$ & $4.75 \pm 0.02$ & $4.56 \pm 0.01$ & $4.44 \pm 1.33$ & $4.59 \pm 0.34^{\mathrm{aa}}$ & \multirow[t]{4}{*}{0.0573} & \multirow[t]{4}{*}{0.3512} & \multirow[t]{4}{*}{0.3529} \\
\hline & 30 & $4.47 \pm 0.01$ & $4.48 \pm 0.02$ & $4.68 \pm 0.02$ & $4.37 \pm 0.01$ & $4.50 \pm 0.02^{\text {aa }}$ & & & \\
\hline & 60 & $4.20 \pm 0.03$ & $4.36 \pm 0.04$ & $4.07 \pm 0.06$ & $3.80 \pm 0.03$ & $4.11 \pm 0.04^{\mathrm{a}}$ & & & \\
\hline & Mean & $4.44 \pm 0.02^{a}$ & $4.53 \pm 0.03^{\mathrm{aa}}$ & $4.44 \pm 0.03^{\mathrm{aa}}$ & $3.72 \pm 0.46^{b}$ & & & & \\
\hline
\end{tabular}

Mean in each row having different superscript varies significantly at values $p<0.05$. Again, mean values having same superscript in each row did not differ significantly at $P>0.05$. Diferent symbols indicate $T_{1}$, Control group; $T_{2}, 5 \%$ wheat flour; $T_{3}, 10 \%$ wheat flour; $T_{4}, 15 \%$ wheat flour; DI, Days of Interval; Treat, Treatment; T*DI, Interaction of Treatment and Days of Interval. 


\section{Microbial assessment}

For microbial assessment total viable count, total coli form count and total yeast-mould count was undertaken. To determine these parameters the procedures which were followed are described briefly; quantity of $10 \mathrm{~g}$ beef meatball sample was aseptically excised from stored stock sample. Each of the stored beef meatball samples was thoroughly and uniformly macerated in a mechanical blender using a sterile diluents $(0.1 \%$ peptone water) as per recommendation of International Organization for Standardization (ISO, 1995).A quantity of ten (10) gram of the minced meat meatball sample was taken aseptically transferred into a sterile container containing $90 \mathrm{ml}$ of $0.1 \%$ peptone water. A homogenized suspension was made in a sterile blender. Thus 1:10 dilution of the samples was obtained. Later on using whirly mixture machine different serial dilutions ranging from $10^{-2}$ to $10^{-6}$ were prepared. Microbiological analyses were determined by Ikhlas et al. (2011).

\section{Statistical analysis}

Data were statistically analyzed using SAS Statistical Discovery software, NC, USA. DMRT test was used to determine the significance of differences among treatments means.

\section{Results}

\section{Sensory evaluation}

Mean scores for different sensory attributes obtained from the sensory evaluation are shown in Table 1. According to Table 1, the range of overall observed color scores at different treatment was 3.90 to 4.57 . The range of odor score among four treatments was 3.89 to 4.33 . The range of overall observed tenderness score at different treatments was 3.89 to 4.22 . The range of overall observed juiciness score at different treatments was 4.23 to 4.63 . The range of different day's interval of overall observation of juiciness score was 4.12 to 4.69 . The data show that the lowest test score was reduced to 4.12 in all treatments after 60 days of storage. The range of overall observed of overall acceptability score at different treatments was 3.72 to 4.53 . The range of different day's interval of overall observation of overall acceptability score was 4.11 to 4.59 . The range of overall observed of overall acceptability score at different treatments was 3.72 to 4.53 . The range of different day's interval of overall observation of overall acceptability score was 4.11 to 4.59 .

Table 2. Effect of different percentage of wheat flour on proximate components in beef meatball

\begin{tabular}{|c|c|c|c|c|c|c|c|c|c|}
\hline & \multirow[t]{2}{*}{ DI } & \multicolumn{4}{|c|}{ Treatments } & \multirow[t]{2}{*}{ Mean } & \multicolumn{3}{|c|}{ Level of significance } \\
\hline & & $\mathrm{T}_{1}$ & $\mathrm{~T}_{2}$ & $\overline{T_{3}}$ & $\mathrm{~T}_{4}$ & & Treat & DI & $\mathrm{T} * \mathrm{DI}$ \\
\hline \multirow{4}{*}{$\begin{array}{c}\text { DM } \\
(\%)\end{array}$} & 0 & $46.32 \pm 0.02$ & $47.16 \pm 0.04$ & $35.77 \pm 0.06$ & $54.59 \pm 0.04$ & $45.96 \pm 0.04^{c}$ & $<.00$ & $<.00$ & $<.0001$ \\
\hline & 30 & $58.14 \pm 0.06$ & $53.49 \pm 0.07$ & $48.71 \pm 0.03$ & $48.36 \pm 0.08$ & $52.18 \pm 0.06^{b}$ & 01 & 01 & \\
\hline & 60 & $60.88 \pm 0.14$ & $56.13 \pm 0.03$ & $51.02 \pm 0.03$ & $49.02 \pm 0.33$ & $54.26 \pm 0.13^{a}$ & & & \\
\hline & Mean & $55.12 \pm 0.07^{a}$ & $52.26 \pm 0.05^{b}$ & $45.17 \pm 0.04^{d}$ & $50.66 \pm 0.15^{c}$ & & & & \\
\hline \multirow{2}{*}{$\begin{array}{c}\text { CP } \\
(\%)\end{array}$} & 0 & $21.89 \pm 0.07$ & $17.70 \pm 0.06$ & $15.23 \pm 0.04$ & $13.49 \pm 0.03$ & $17.08 \pm 0.05^{a}$ & $<.00$ & $<.00$ & $<.0001$ \\
\hline & Mean & $20.82 \pm 0.05^{a}$ & $17.27 \pm 0.04^{b}$ & $15.78 \pm 0.05^{c}$ & $13.29 \pm 0.03^{d}$ & & & & \\
\hline \multirow{4}{*}{$\begin{array}{c}\text { EE } \\
(\%)\end{array}$} & 0 & $5.33 \pm 0.16$ & $5.00 \pm 0.03$ & $4.77 \pm 0.02$ & $4.67 \pm 0.03$ & $4.94 \pm 0.06^{a}$ & $<.00$ & $<.00$ & $<.0001$ \\
\hline & 30 & $5.97 \pm 0.03$ & $4.99 \pm 0.02$ & $4.62 \pm 0.03$ & $4.50 \pm 0.02$ & $5.02 \pm 0.03^{\text {aa }}$ & 01 & 01 & \\
\hline & 60 & $4.91 \pm 0.07$ & $4.95 \pm 0.02$ & $4.40 \pm 0.03$ & $4.24 \pm 0.02$ & $4.63 \pm 0.04^{b}$ & & & \\
\hline & Mean & $5.40 \pm 0.09^{a}$ & $4.98 \pm 0.02^{b}$ & $4.60 \pm 0.03^{c}$ & $4.47 \pm 0.02^{d}$ & & & & \\
\hline
\end{tabular}

Mean in each row having different superscript varies significantly at values $p<0.05$. Again, mean values having same superscript in each row did not differ significantly at $\mathrm{P}>0.05$. Diferent symbols indicate $\mathrm{T}_{1}$, Control group; $\mathrm{T}_{2}, 5 \%$ wheat flour; $\mathrm{T}_{3}, 10 \%$ wheat flour; $\mathrm{T}_{4}, 15 \%$ wheat flour; DI, Days of Interval; Treat, Treatment; $\mathrm{T} * \mathrm{DI}$, Interaction of Treatment and Days of Interval. 


\section{Proximate analysis}

Proximate compositions of beef meatball as influenced by wheat flour during storage are shown in Table 2 . The range of overall observed DM content at different treatments was 45.17 to $55.12 \%$. The range of overall observation of different days of interval of DM content was 45.96 to $54.26 \%$. The range of overall observed $\mathrm{CP}$ content at different treatments was 13.29 to $20.82 \%$. The range of overall observed of different days of intervals of $\mathrm{CP}$ content was 16.52 to $17.08 \%$. The data show that the lowest amount of CP content was decreased to 16.52 in all treatments after 60days of storage. The range of overall observed EE content at different treatments was 4.47 to $5.40 \%$. The range of overall observed of different days of intervals of EE content was 4.63 to $5.02 \%$. The range of overall observed Ash content at different treatments was 1.63 to $2.24 \%$. The range of overall observed Ash content at different treatments was 1.63 to $2.24 \%$.

\section{Physicochemical properties}

The range of overall observed raw $\mathrm{pH}$ at different treatments was 5.67 to 5.83 . The range of overall observed cooked $\mathrm{p}^{\mathrm{H}}$ at different treatments was
9.93 to 9.98 . The range of overall observed cooking loss at different treatments was 24.70 to $16.72 \%$ (Table 3).

\section{Biochemical properties}

FFA results appeared to be consistent with those of TBARs and POV. The number of FFA increased with storage time (Table 4 ). The range of overall observed of different days of intervals of FFA was 0.20 to 0.32 . The FFA value was increased with storage period. The range of overall observed FFA value at different treatments was 0.20 to 0.35 . At the end of the storage time (day 60), the FFA value in the control sample (0.35) was significantly $(p<0.05)$ higher than the values in the samples treated with natural fiber. The range of overall observed peroxide value at different treatment levels was 2.46 to 3.91 . The range of overall observed of different days of intervals of peroxide value was 2.59 to 3.01. Generally, TBARs levels significantly $(p<0.05)$ increased with storage time, showing decreasing shelf life. The range of overall observed of different days of intervals of TBARs value was 0.22 to 0.25 .

Table 3: Effect of different percentage of wheat flour on others parameters in beef meatballs

\begin{tabular}{|c|c|c|c|c|c|c|c|c|c|}
\hline \multirow[t]{2}{*}{$\begin{array}{l}\text { Parame } \\
\text { ters }\end{array}$} & \multirow[t]{2}{*}{ DI } & \multicolumn{4}{|c|}{ Treatments } & \multirow[t]{2}{*}{ Mean } & \multicolumn{3}{|c|}{$\begin{array}{c}\text { Level of } \\
\text { significance }\end{array}$} \\
\hline & & $\mathrm{T}_{1}$ & $\mathrm{~T}_{2}$ & $\mathrm{~T}_{3}$ & $T_{4}$ & & $\begin{array}{c}\mathrm{Tr} \\
\text { ea } \\
\text { t. }\end{array}$ & DI & $\begin{array}{c}T^{*} \mathrm{D} \\
\mathrm{I}\end{array}$ \\
\hline \multirow[t]{4}{*}{ Raw $\mathbf{P}^{\mathbf{H}}$} & 0 & $5.69 \pm 0.02$ & $5.86 \pm 0.03$ & $5.83 \pm 0.01$ & $5.92 \pm 0.01$ & $5.83 \pm 0.02^{a}$ & \multirow{4}{*}{$\begin{array}{l}<. \\
00 \\
01\end{array}$} & \multirow{4}{*}{$\begin{array}{l}<. \\
00 \\
01\end{array}$} & \multirow{4}{*}{$\begin{array}{l}0.0 \\
051\end{array}$} \\
\hline & 30 & $5.70 \pm 0.01$ & $5.72 \pm 0.01$ & $5.79 \pm 0.02$ & $5.84 \pm 0.02$ & $5.77 \pm 0.02^{b}$ & & & \\
\hline & 60 & $5.61 \pm 0.01$ & $5.65 \pm 0.01$ & $5.74 \pm 0.02$ & $5.74 \pm 0.02$ & $5.69 \pm 0.02^{c}$ & & & \\
\hline & Mean & $5.67 \pm 0.01^{d}$ & $5.74 \pm 0.02^{c}$ & $5.79 \pm 0.02^{b}$ & $5.83 \pm 0.02^{a}$ & & & & \\
\hline \multirow{4}{*}{$\begin{array}{l}\text { Cooked } \\
\mathbf{P}^{\mathbf{H}}\end{array}$} & 0 & $6.01 \pm 0.04$ & $6.03 \pm 0.02$ & $6.05 \pm 0.03$ & $6.08 \pm 0.02$ & $6.05 \pm 0.03^{a}$ & \multirow{4}{*}{$\begin{array}{l}0 . \\
22 \\
53\end{array}$} & \multirow{4}{*}{$\begin{array}{l}<. \\
00 \\
01\end{array}$} & \multirow{4}{*}{$\begin{array}{l}0.4 \\
374\end{array}$} \\
\hline & 30 & $5.92 \pm 0.05$ & $5.97 \pm 0.02$ & $5.96 \pm 0.03$ & $5.89 \pm 0.04$ & $5.94 \pm 0.04^{b}$ & & & \\
\hline & 60 & $5.83 \pm 0.06$ & $5.93 \pm 0.01$ & $5.89 \pm 0.02$ & $5.83 \pm 0.01$ & $5.88 \pm 0.03^{c}$ & & & \\
\hline & Mean & $5.93 \pm 0.05^{a}$ & $5.98 \pm 0.02^{\mathrm{aa}}$ & $5.97 \pm 0.03^{\mathrm{aa}}$ & $5.94 \pm 0.02^{\mathrm{aa}}$ & & & & \\
\hline \multirow{4}{*}{$\begin{array}{l}\text { Cooking } \\
\text { loss } \\
(\%)\end{array}$} & 0 & $26.96 \pm 0.08$ & $25.22 \pm 0.06$ & $17.70 \pm 0.09$ & $22.19 \pm 0.03$ & $23.02 \pm 0.07^{a}$ & \multirow{4}{*}{$\begin{array}{l}<. \\
00 \\
01\end{array}$} & \multirow{4}{*}{$\begin{array}{l}<. \\
00 \\
01\end{array}$} & \multirow{4}{*}{$\begin{array}{l}<.0 \\
001\end{array}$} \\
\hline & 30 & $24.58 \pm 0.04$ & $23.60 \pm 0.03$ & $16.61 \pm 0.05$ & $21.17 \pm 0.04$ & $21.49 \pm 0.04^{b}$ & & & \\
\hline & 60 & $22.56 \pm 0.03$ & $21.92 \pm 0.04$ & $15.84 \pm 0.02$ & $19.95 \pm 0.02$ & $20.07 \pm 0.03^{c}$ & & & \\
\hline & Mean & $24.70 \pm 0.05^{a}$ & $23.58 \pm 0.04^{b}$ & $16.72 \pm 0.05^{d}$ & $21.11 \pm 0.03^{c}$ & & & & \\
\hline
\end{tabular}

Mean in each row having different superscript varies significantly at values $p<0.05$. Again, mean values having same superscript in each row did not differ significantly at $\mathrm{P}>0.05$. Diferent symbols indicate $\mathrm{T}_{1}$, Control group; $\mathrm{T}_{2}, 5 \%$ wheat flour; $\mathrm{T}_{3}, 10 \%$ wheat flour; $\mathrm{T}_{4}, 15 \%$ wheat flour; DI, Days of Interval; Treat, Treatment; $\mathrm{T} * \mathrm{DI}$, Interaction of Treatment and Days of Interval. 


\section{Microbiological assessment}

From the study the range of overall observed aerobic plate count from the beef meatballs was 6.59-7.12 $(\log 10 \mathrm{CFU} / \mathrm{g})$, at different treatment levels (Table 5). Among four treatments, the plate count in the $\mathrm{T}_{2}$ ( $5 \%$ wheat flour) sample (7.12 log $\mathrm{CFU} / \mathrm{g}$ ) was significantly higher than other treated group including control group. The range of overall observed total coliform count from the beef meatballs was 1.89-2.19 (log $\mathrm{CFU} / \mathrm{g}$ ) at different treatment levels. Among four treatments, the total coliform count in the control sample (2.19 logs CFU/g) was significantly higher than in the samples treated with natural fiber as wheat flour $5 \%, 10 \%, 15 \%$ group. The range of overall observed of different days of intervals of TCC value was 1.64 to 2.44. The range of overall observed total yeast-mold count from the beef meatballs was 2.71 to $3.17(\log \mathrm{CFU} / \mathrm{g})$. The value of the range of overall observed of different days of intervals of TYMC value was 1.79 to 1.04 .

\section{Discussion}

Value added meatball was formulated supplemented with different level of wheat flour as dietary fiber and prebiotics. From the study it was found that the sensory quality after supplementation with higher level of wheat flour was deteriorated and it was pronounced with increased storage period. The present findings is in agreement with Gonzalez et al. (2008) where he stated that dried plum ingredients in raw and precooked pork sausage negatively affected the sensory attributes such as color, texture, odor, and flavor as well as the nutritional quality of the product. Some authors also reported that inclusion of fibers in various meat products increased hardness (Fernandez-Gines et al., 2004).That's why meatballs leak juices when they are stored. If meatballs refrozen accelerating further moisture loss, and when this meatballs eventually cook, any one may find it dense and dry in texture.

The dry matter content was increased with the increased storage period because moisture loss was decreased with the storage period. The data show that the highest amount DM content was increased to 54.26 in all treatments after 60 days of storage. The highest amount of DM content indicates this product is less preferable. Dry matter increased for the moisture loss of beef meatball samples with the advance of storage time during freezing. Devatkal et al. (2010) also reported that incorporation pomegranate rind and seed powder extracts did not affect the DM content of goat meat patties. Cooked lemon albedo fibers (2.5 to $5 \%$ ) in bolognas showed higher moisture content than control (FernandezGines et al., 2004).The CP content was decreased with the increased storage period. Wheat fiber group contains lower amount of EE than control group. The Malaysian Food Regulation of 1985 stated that manufactured meat should not contain more than $30 \%$ fat. Malaysian beef meatballs can be classified as lowfat meatballs since the fat content ranges from 1.69 to 11.09.Verma et al. (2012) reported significant decrease in low fat chicken nuggets incorporated with chickpea hull flour. The Ash content was significantly changed with the increased storage period. The same trend was also observed by Konieczny et al. (2007) and they reported that ash content increased during frozen storage which is related to our findings.

Table 4: Effect of different levels of wheat flour on biochemical parameters in beef meatballs

\begin{tabular}{|c|c|c|c|c|c|c|c|c|c|}
\hline \multirow[t]{2}{*}{ Parameters } & \multirow[t]{2}{*}{ DI } & \multicolumn{4}{|c|}{ Treatments } & \multirow[t]{2}{*}{ Mean } & \multicolumn{3}{|c|}{ Level of significance } \\
\hline & & $\mathrm{T}_{1}$ & $\mathrm{~T}_{2}$ & $T_{3}$ & $\mathrm{~T}_{4}$ & & Treat. & $\mathrm{DI}$ & $\mathrm{T} * \mathrm{DI}$ \\
\hline \multirow[t]{3}{*}{ FFA (\%) } & 0 & $0.30 \pm 0.00$ & $0.19 \pm 0.00$ & $0.04 \pm 0.01$ & $0.27 \pm 0.00$ & $0.2 \pm 0.00^{c}$ & \multirow[t]{3}{*}{$<.0001$} & \multirow[t]{3}{*}{$<.0001$} & \multirow[t]{3}{*}{$<.0001$} \\
\hline & 30 & $0.39 \pm 0.00$ & $0.20 \pm 0.00$ & $0.35 \pm 0.00$ & $0.31 \pm 0.00$ & $0.32 \pm 0.00^{b}$ & & & \\
\hline & Mean & $0.35 \pm 0.00^{\mathrm{a}}$ & $0.20 \pm 0.00^{d}$ & $0.25 \pm 0.00^{c}$ & $0.31 \pm 0.00^{b}$ & & & & \\
\hline \multirow[t]{2}{*}{ PV (meq/kg) } & 0 & $3.58 \pm 0.11$ & $2.56 \pm 0.04$ & $2.19 \pm 0.01$ & $2.03 \pm 0.03$ & $2.59 \pm 0.05^{c}$ & \multirow[t]{2}{*}{$<.0001$} & \multirow[t]{2}{*}{$<.0001$} & \multirow[t]{2}{*}{$<.0001$} \\
\hline & 30 & $3.95 \pm 0.02$ & $2.46 \pm 0.03$ & $2.35 \pm 0.01$ & $2.84 \pm 0.01$ & $2.90 \pm 0.02^{b}$ & & & \\
\hline \multirow{4}{*}{$\begin{array}{l}\text { TBARs } \\
(\text { mg-MA/kg) }\end{array}$} & 0 & $0.22 \pm 0.01$ & $0.14 \pm 0.00$ & $0.22 \pm 0.00$ & $0.28 \pm 0.00$ & $0.22 \pm 0.00^{b}$ & \multirow[t]{4}{*}{$<.0001$} & \multirow[t]{4}{*}{$<.0001$} & \multirow[t]{4}{*}{$<.0001$} \\
\hline & 30 & $0.22 \pm 0.00$ & $0.14 \pm 0.00$ & $0.25 \pm 0.02$ & $0.28 \pm 0.00$ & $0.22 \pm 0.01^{\mathrm{bb}}$ & & & \\
\hline & 60 & $0.31 \pm 0.00$ & $0.14 \pm 0.00$ & $0.24 \pm 0.01$ & $0.29 \pm 0.00$ & $0.25 \pm 0.00^{\mathrm{a}}$ & & & \\
\hline & Mean & $0.28 \pm 0.00^{b}$ & $0.14 \pm 0.00^{d}$ & $0.24 \pm 0.01^{c}$ & $0.26 \pm 0.00^{a}$ & & & & \\
\hline
\end{tabular}


Mean in each row having different superscript varies significantly at values $p<0.05$. Again, mean values having same superscript in each row did not differ significantly at $P>0.05$. Diferent symbols indicate $T_{1}$, Control group; $\mathrm{T}_{2}, 5 \%$ wheat flour; $\mathrm{T}_{3}, 10 \%$ wheat flour; $\mathrm{T}_{4}, 15 \%$ wheat flour; DI, Days of Interval; Treat, Treatment; T*DI, Interaction of Treatment and Days of Interval.

Among these four treatments most preferable raw $\mathrm{pH}$ was observed from T4 (15\% wheat flour) group. The highest amount of raw $\mathrm{pH}$ indicates this product is highly preferable for consumers' health than other treatment groups. The data showed a slight increase in the raw $\mathrm{pH}$ values and a decrease in the acidity values for all samples along with addition of natural fiber as a result of the decrease of free fatty acids due to lower rancidity. The decrease in the raw $\mathrm{pH}$ values was lower in the untreated samples than the treated ones due to the effect of wheat fiber which retarded the formation of free fatty acids. It is also obvious that the values of raw $\mathrm{pH}$ for the product were higher than that of the raw $\mathrm{pH}$ values of meat and this could be due to the interaction effect of the other ingredients which were added during the processing of meat products. The range of overall observed of different days of intervals of raw $\mathrm{pH}$ was 5.69 to $5.83 \%$. The raw $\mathrm{pH}$ was decreased with the increased storage period. Bacteria and mold have a tendency to increase with increasing storage time, and they secrete components that affect the increasing raw pH. Choi et al. (2009) reported that meat batter containing dietary fiber from rice bran have higher $\mathrm{pH}$ values. The data showed a slight increase in the cooked $\mathrm{pH}$ values and a decrease in the acidity values for all samples along with addition of wheat fiber as a result of the decrease of free fatty acids due to lower rancidity. The decrease in the cooked $\mathrm{pH}$ values was lower in the untreated samples than the treated ones due to the effect of wheat fiber which retarded the formation of free fatty acids. The highest amount of cooked $\mathrm{pH}$ indicates this product is most preferable for consumers' health than other treatment groups. The range of overall observed of different days of intervals of cooked $\mathrm{PH}$ was 5.88 to 6.05 . The cooked $\mathrm{pH}$ was decreased with the increased storage period.

The lowest amount of cooking loss indicates this product is most preferable for consumers' choice than other treatment groups. The range of overall observed of different days of intervals of cooking loss was 20.07 to $23.02 \%$. The cooking loss was decreased with the increased storage period. The less preferable cooking loss was observed from 0 day and most preferable cooking loss was observed from 60th day observation. Cooking loss refers to the reduction in weight of meatballs during the cooking process (Jama et al. 2008). Dietary fiber supplementations increase the bulk and prevent cooking loss in meat products with no or fewer changes in textural parameters by enhancing water binding capabilities and carries great economic advantages for both the consumers and processors (Grigelmo-Miguel et al., 1999). Turhan et al. (2005) reported that addition of hazelnut pellicle fiber was found to be effective in improving cooking yield, dimensional changes and thickness of beef burgers.

Meat with higher lipid oxidation values also showed higher protein oxidation and greater metmyoglobin formation. Lundet et al. (2007) reported on the peroxide values in sausage with three treatments (rosemary extract, collagen fiber preparation impregnated with rosemary extract and collagen hydrolyses impregnated with rosemary extract; samples with these three treatments showed lower values than the control. The lowest amount peroxide value indicates this product is most preferable for consumes health. Less preferable peroxide value was observed from control group. The highest amount of peroxide value indicates this product is less preferable. The lowest amount of TBARs value indicates this product is most preferable for consumes health. Less preferable TBARs value was observed from control group. The results of this study confirm that 5\%,10\%, $15 \%$ wheat flour can delay lipid oxidation significantly, reducing the potential risk induced by lipid oxidation. Higher values were observed in the control treatment, while values of 0.025 and $0.05 \%$ were observed in the sample treated with rosemary extract. 
Table 5: Effect of different level of wheat flour on microbial in beef meatballs

\begin{tabular}{|c|c|c|c|c|c|c|c|c|c|}
\hline $\begin{array}{l}\text { Param } \\
\text { eters }\end{array}$ & DI & $\mathrm{T}_{1}$ & $\mathrm{~T}_{2}$ & $\mathrm{~T}_{3}$ & $\mathrm{~T}_{4}$ & Mean & Treat. & DI & $\mathrm{T} * \mathrm{DI}$ \\
\hline \multirow{3}{*}{$\begin{array}{l}\text { TVC } \\
(\log C F \\
\text { U/g) }\end{array}$} & 0 & $6.83 \pm 0.04$ & $7.08 \pm 0.04$ & $6.63 \pm 0.03$ & $7.17 \pm 0.03$ & $6.94 \pm 0.04^{b}$ & \multirow[t]{3}{*}{$<.0001$} & \multirow[t]{3}{*}{$<.0001$} & \multirow[t]{3}{*}{0.1241} \\
\hline & 60 & $7.02 \pm 0.03$ & $7.19 \pm 0.03$ & $6.72 \pm 0.01$ & $7.19 \pm 0.03$ & $7.03 \pm 0.03^{a}$ & & & \\
\hline & Mean & $6.88 \pm 0.04^{b}$ & $7.12 \pm 0.03^{\mathrm{aa}}$ & $6.59 \pm 0.06^{c}$ & $7.08 \pm 0.05^{a}$ & & & & \\
\hline \multirow{2}{*}{$\begin{array}{l}\text { TCC } \\
(\log C F \\
U / g)\end{array}$} & 0 & $2.51 \pm 0.05$ & $2.28 \pm 0.02$ & $2.66 \pm 0.07$ & $2.31 \pm 0.02$ & $2.44 \pm 0.04^{a}$ & \multirow[t]{2}{*}{$<.0001$} & \multirow[t]{2}{*}{$<.0001$} & \multirow[t]{2}{*}{$<.0001$} \\
\hline & 60 & $1.82 \pm 0.06$ & $1.31 \pm 0.05$ & $1.79 \pm 0.03$ & $1.61 \pm 0.02$ & $1.64 \pm 0.04^{c}$ & & & \\
\hline
\end{tabular}

Mean in each row having different superscript varies significantly at values $p<0.05$. Again, mean values having same superscript in each row did not differ significantly at $P>0.05$. Diferent symbols indicate $T_{1}$, Control group; $\mathrm{T}_{2}, 5 \%$ wheat flour; $\mathrm{T}_{3}, 10 \%$ wheat flour; $\mathrm{T}_{4}, 15 \%$ wheat flour; DI, Days of Interval; Treat, Treatment; $T^{*} \mathrm{DI}$, Interaction of Treatment and Days of Interval.

The range of overall observed of different days of intervals of TVC value was 6.78 to 7.03 . During storage TVC value was increased. The initial value of TVC for fresh beef was 5.12 logs CFU/g beefs, indicating good quality beef. Cross-contamination from the environment or from the survival of spores or resistant cells was possible in this study as well as in commercial operations. Plantderived spices are generally used in foods or flavorings and for medicinal purposes. However, a number of studies have demonstrated that compounds existing in many spices also possess antimicrobial activity (Zhang et al., 2009). The initial level of contamination (aerobic count) was relatively low (3.18 log10 CFU/g). During storage TCC value was decreased. During storage TYMC value was decreased. Fernández-López et al. (2003) reported on the results of a research study related to antimicrobials in beef meatballs. They noted that the presence of mold and yeasts was not detected in any cooked meatball samples.

\section{Conclusion}

This study reveals that among four treatments most preferable color, odor, tenderness, juiciness and overall acceptability was observed at $5 \%$ wheat flour group and less preferable color was observed from control group. Less cooking loss was observed at $10 \%$ wheat flour group. The lowest FFA, PV and TBARs value were observed in $5 \%$ wheat flour group. It is recommended that $5 \%$ wheat flour can be used as a source of dietary fiber and functional ingredients as prebiotics in meatball.

\section{Acknowledgement}

We would like to express our appreciation to the Bangladesh Agricultural University Research System (BAURES) for funding this research and their encouragement. 


\section{References}

AOAC (2016).Official Methods of Analysis. (20 th Edition) Association of Official Analytical Chemists. Washington, DC, USA.

Borderias AJ, I Sanchez-Alonso and M Perez-Mateos (2005). New applications of fibers in foods: addition to fishery products. Trends in Food Science and Technology. 16: 458-465.

Choi YS, H Doo-Jeong, K,Mi-Ai, L Hack-Young, Hyun-WookJ, $\mathrm{K}$ jong-youn and Jei $\mathrm{K}$, cheon (2009). Characteristics of low -fat meat emulsion systems with pork fat replaced by vegetable oils and rice bran fiber.Meat Science, 82(2): 266-271.

Chau CF, and.PCK Cheung (1999). Effects of the physico-chemical properties of three legume fibers on cholesterol absorption in hamsters. Nutrion Research, 19 (2): 257-265.

Devatkal SK, K Narsaiah, and A Borah (2010).Antioxidant effect of extracts of kinnow rind, pomegranate rind and seed powders in cooked goat meat patties. Meat Science, 85: 155-159.

Fernandez- Lopey J, J M Fernandez- Gines,, L Aleson- Carbonell, E Sayas- Barberia, E Sendra and JA Perez- Alvarez (2003). Functional components from citrus by products and their application in meat products. Trend in Food science and Technology, 15:176-185.

Ferna'ndez-Gine's JM, J Ferna'ndez-Lo'pez, M E Sayas-Barbera. E Sendra, and J A Pe'rezAlvarez (2004). Lemon albedo as a new source of dietary fiber: Application to bologna sausage. Meat Science, 67: 7-13.

Gonzalez ND, RM Boleman, RK Miller and Rhee KS (2008). Antioxidant properties of dried plum ingredients in raw and precooked pork sausage, Food Science. 73(5):H63-71.

Grigelmo-Mugel N, M Abadias- Seros and O,MartinBelloso (1999). Meat Science, 52: 247-256.

ISO (1995). International Organization for Standardization. Recommendation of the meeting of the sub-committee on meat and meat products, ISO/ TC-36/SC-6 10-18.

Ikhlas B, I Huda, and $\mathrm{N}$ Ismail (2011). Effect of cosmos Caudatus, Polygonum minus and BHT on Physical properties, Oxidation process, and microbiological growth of quail meatball during refrigeration storages. Journal of Food Processing and preservation ISSN 1745-4549.

Jama N, V Muchenje, M Chimonyo, P E Strydom, K Dzama and JG Raats (2008). Cooking loss components of beef from Nguni, Bonsmara and Angus steers. African Journal of Agricultural Research, 3 (6): 416-420.

Konieczny P, J Stangiershi and J Kijowski (2007). Physical and chemical characteristics and acceptability of home style beef jerky meat, Meat Science, 76: 253-257
KNS (2010). Korian Nutritional Sciences. Seoul, Korea.

Lundet MN, MS Hviid and L H Skibsted (2007). The combined effect of antioxidants and modified atmosphere packaging on protein lipid oxidation in beef patties during storage. Meat Science, 76: 226-233.

Rubio B, B Martinej, MJ Sinchey, MD Garcia-cachan, J Rovira and I Jaime (2007). Study of self-life of a dry fermented sausage Salchichon made from raw material enriched in monounsaturated and polyunsaturated fatty acids and stored under modified atmospheres. Meat Science 76: 128/137.

Rukumudin IH, PJ White, CJ Bern and TB Bailey (1998). A modified method for determining free fatty acids from small soybean sample sizes. Journal of American Oil Chemistry Society, 75: 563-568.

Saricoban C, MT Yilmaz and M Karakaya (2009). Response surface methodology study on the optimization of effects of fat, wheat bran and salt on chemical, textural and sensory properties of patties. Meat Science. 83: 610619.

Sallam KI, M Ishioroshi and K Samejima (2004). Antioxidants and antimicrobial effects of garlic in chicken sausage. Food Science and technology, 37(8): 849-855.

Schemedes A and G Holmer (1989). A new Thiobarbituric acid (TBA) method for determining free malondialdehyde and hydroperoxides selectively as a measure of lipid peroxidation. Journal of .African Oil Chemistry Society 66: 813-817.

Talukder S and DP Sharma (2010). Development of dietary fiber rich chicken meat patties using wheat and oat bran. Journal of Food Science and Technology. 47: 224-229.

Turhan S and I Sagir and NS Utsan (2005). Utilization of hazel nut pellicle in low -fat beef burgers, Meat Science, 71(2): 312-316.

USDA (2010). United States of Drug Administration.

Verma AK, R Banerjee and BD Sharma (2012). Quality of low fat chicken nuggets: Effect of sodium chloride replacement and added chickpea (Cicerarietinum L.) hull flour. AsianAustralian Journal of Animal Science, 25:291298.

Zhang H, K Boahua, LX youn ling and X Sun (2009). Antimicrobial activities of spices extracts against pathogenic and spoilage bacteria in modified atmosphere packaged fresh pork and vacuum packaged ham slices stored at $4^{\circ} \mathrm{C}$. Meat Science. 81(4): 686-692. 